\title{
Some Thoughts on Qallunaat Teacher Caring in Nunavut
}

\author{
Paul Berger \\ Lakehead University
}

\begin{abstract}
Qallunaat (non-Inuit) teaching Inuit students in Nunavut risk being agents of the continuing colonialism of EuroCanadian schooling (Berger, 2005). I argue that for a Qallunaat teacher to be a caring teacher this and related issues must be faced. I claim that an extraordinary commitment, expressed in actions, is required from individual teachers, and discuss the near impossibility of truly caring in the absence of change in the very Western way schooling is conducted in Nunavut.
\end{abstract}

Almost all teachers would probably claim to care about their students, but that is not enough to ensure caring occurs. Caring includes professional fretting, personal inclination toward a person, and responsibility for an other person's protection and welfare in a way that is not "perfunctory or grudging" (Noddings, 1984). Caring requires, Noddings wrote, "a displacement of interest from my own reality to the reality of the other" (p. 14) and "action on behalf of the caredfor" (p. 10). The teacher who cares is one who desires the well-being of students and acts in ways that promote it.

Caring teaching is demanding; "in a fundamental, essential way, caring implies a quest for competence" (Noddings, 1996, p. 162), and, for a Qallunaat teacher in Nunavut, competence is needed in many realms, including understanding differences in culture and the historical and present relationship between Qallunaat and Inuit. Good intentions will not be enough to save the Qallunaat teacher from making potentially damaging cultural blunders, using ineffective pedagogy, and teaching students away from their culture. A high level of commitment, but also reflection, growth, advocacy, and collaboration with Inuit, is needed, and the desire to care is complicated by the fact that the very idea of how one cares differs across cultures (Noddings).

Due to systemic constraints discussed in more detail below and because caring differs across cultures, for true caring to be possible changes in schooling are needed, and the changes should be guided by Inuit. Otherwise, even the Qallunaat educator who wants to care deeply risks paternalism and enactment of the colonial relationship that must be challenged, as she or he is forced to make decisions that should be the providence of Inuit (United Nations, 2006). Within this context I suggest some considerations for the Qallunaat teacher who wants to care. As a EuroCanadian, simply expressing these thoughts carries the risk of

Paul taught Grade 7 for 2 years in Nunavut and is currently doing PhD research on Inuit wishes for schooling in one community in Nunavut. An earlier version of this paper was presented at the One Vision-Many Voices, Cross-Cultural/Anti-Racism Education Conference at the University of Alberta, November 17-19, 2005. 
continued colonialism. Inuit should have authentic control of education in Nunavut, and Inuit voices should inform all aspects of Inuit education. I offer these thoughts as ideas to consider on the way from a colonial Qallunaat-based education system to an education system under true Inuit control.

\section{Historical Context}

Qallunaat schools-schools based on a EuroCanadian model-were established in the Eastern Arctic 50 years ago as instruments of Canadian colonial policy, designed by the federal government to force Inuit from the land into communities as part of a strategy to ensure Canadian sovereignty in the Arctic (Prattis \& Chartrand, 1990; Tester \& Kulchyski, 1994). Qallunaat schooling was imposed without consultation and replaced the Inuit ways of educating and socializing that were embedded "in the immediate practice of everyday Inuit life" (Nungak, 2004, p. 15). Initially staffed wholly by Qallunaat, schools were structured on southern Canadian norms, operated in English, used curriculum from the southern provinces, and were controlled from afar (Van Meenen, 1994). A foreign curriculum was being taught by foreigners in a foreign language (McAuley, 1991).

The Nunavut Social Development Council [NSDC] (2000) described some of the consequences of contact and EuroCanadian colonisation as "social havoc... intense...change...abysmal levels of education," and a "national disgrace...a scandal that Canada hardly acknowledges" (pp. 71-74). Nunavut experiences social problems so serious that "if they were replicated elsewhere in Canada, there would be a public outcry of national proportions, serious enough to topple a government" (p. 83). These problems include high unemployment and a low median income, high addiction and suicide rates, overcrowded housing, and lower health status than any other province or territory (NSDC; Prattis \& Chartrand, 1990; Tester, 2006). Qallunaat schools share responsibility for this cultural disruption and its consequences (Brody, 1991; Crago, 1992; Lipka, Mohatt, \& the Ciulistet Group, 1998).

The schools continue to assimilate students to EuroCanadian culture despite some important changes since their inception. These changes include the hiring of many Inuit teachers at the primary and junior levels, the use of Inuktitut in the early grades, and the development of new curriculum. The assimilation of Inuit students continues because the schools remain dominated by southern Canadian curriculum, resources, and teaching methods, and because the norms and values of Qallunaat culture are embodied in both the structure of Western schooling and the ways of being of the Qallunaat teachers, who still comprise the majority of teachers in Nunavut.

In 1999, Nunavut, with an 85\% Inuit population, became Canada's newest territory (Hicks, 2005). The territory was part of a land claims agreement with the Government of Canada that was meant, in part, to protect Inuit cultural vitality by moving decision-making to a public government elected by a majority Inuit electorate. Unfortunately, adopting the structure of government from the Northwest Territories effectively precluded the possibility of forming a truly "Inuit" government (Inuit Qaujimajatuqanginnut Task Force, 2002). Still, having inherited a colonial school system, the Nunavut Department of Education made moves to determine community wishes for schooling through community 
consultations (Aylward, 2004) and through further consultations for the proposed Nunavut Education Act (Picco, 2006); these moves were to help increase Inuit input into schooling in Nunavut. Both consultations suggested that Inuit ways must become a much greater part of schooling in Nunavut, and the Minister of Education, a Qallunaat, committed to an Education Act "based on Inuit societal values" (Picco, p. 1).

In the literature on minority and cross-cultural education, local control is thought to be essential for student success and well-being (Cummins, 1986; Harris, 1990; Kirkness, 1998; Lipka, 1989; Simon, 1996). Inuit must have the power to structure schooling in ways that they see fit, although "the legacy of colonialism has left tremendous power imbalances between Inuit and Qallunaat" (Tompkins, 2002, p. 407), making this more difficult. In this complicated and still colonial context, how might a Qallunaat teacher care?

\section{Avenues of Caring}

Indigenous peoples have the right to determine the form and content of their children's education (United Nations, 2006). Following recent consultations (Aylward, 2004; Picco, 2006) it is clear that the current system does not meet Inuit expectations. Just maintaining the status quo in this system does not demonstrate caring-it maintains the Qallunaat teacher's role in a school system that was and still is colonizing (Berger, 2005). In the following sections I present ideas about what Qallunaat teachers in Nunavut might do to be caring, I address the need for systemic change to make true caring possible, and I suggest that respect and engagement are good starting points for Qallunaat teachers of Inuit students.

\section{Caring and the impossibility of teacher neutrality}

Although there is a commonly held belief that teachers should be neutral in the sense of being unbiased, of presenting both sides of controversial issues fairly (Kelly, 2001), the act of teaching is political and education is never neutral (Freire, 2001; Giroux, 1999). According to Portelli (2001), "since we do not live in a completely neutral context, the teacher is inevitably bound to influence the students even by his or her very presence in class" (p. 289). Even the words we choose are directed by values (Jickling, 2003). Okakok (1989) illustrated the value-laden nature of routine school practices in Alaska:

I think teachers pass down values by what they do in certain situations. Showing approval to a child for quickly attempting to answer a question-even wrongly-is valuing a quick answer to questions. At home, this same child may have been taught not to say anything until he or she has observed and observed and observed, and feels certain that his of her answer is correct. At home, the parents value accuracy more highly than a quick answer. (p. 412, emphasis in original)

There are significant value differences between historical Inuit culture and Qallunaat school culture, including respect for the autonomy of the child versus an expectation of submission to authority, a cooperative versus a competitive orientation, and a focus on the well-being of the group rather than on the 
achievement of the individual (Bould, n.d.; Brody, 2000; Stairs, 1994). It is impossible for a Qallunaat teacher to be neutral, or apolitical, and teach for student well-being if these differences are ignored. In schooling designed by Qallunaat, the ideological underpinnings are non-Inuit and push Inuit students toward EuroCanadian norms and values. Serious culture change has already taken place (NSDC, 2000; Stairs, 1988), and, although cultures are not static and change is to be expected, forced change under colonial pressure threatens the vitality of minority cultures (Harris, 1990; Lipka, 1989).

For Qallunaat teaching Inuit, good intentions alone do not challenge the status quo that risks harm to students and Inuit culture. Because the schools still assimilate Inuit students, just teaching "well" and increasing student achievement may, in fact, mean faster assimilation and more rapid loss of Inuit culture (Crago \& Eriks-Brophy, 1994; Doige, 1999). In the words of the NSDC (2000), "the education system is culturally flawed and only by incorporating the values of Inuit and using the Inuit language can it come to terms with Inuit society and help Inuit youth adapt to the modern world" (p. 82). Qallunaat teachers need to work toward decolonizing schooling in Nunavut by respecting Inuit culture and advocating for the right of Inuit to self-determination in schooling-an active, political stance. In the context of colonial schools, neutrality is not compatible with caring.

\section{Caring and curriculum}

Goddard (2002) wrote that a failure by White educators in First Nations schools "to contest the curriculum indicates that they do not take issue with the hegemonic domination of the neocolonial settler state" (pp. 130-131). In Nunavut, many Qallunaat teachers do contest the curriculum (Berger, 2001), most of which still comes from southern Canada. This material is "loaded with implied cultural content" (Wolforth, 1998, p. 568) and was not designed for students whose first language is not English, although some curriculum has been modified to better suit the northern environment and Inuuqatigiit: The curriculum from the Inuit perspective (Northwest Territories Education, Culture and Employment [NWTECE], 1996) was created to reflect traditional Inuit learnings.

Qallunaat teachers sometimes deal with inappropriate southern curriculum by modifying it or discarding it entirely (Berger, 2001). Modifying or creating curriculum and resources that are more culturally relevant takes time and energy and carries with it the risk of censure from administrators (Tompkins, 1998). Caring, though, sometimes requires breaking rules (Noddings, 1984); some curricular autonomy is needed for teachers to be able to meet students' needs (Noddings, 1996). To alter curriculum effectively the teacher must have knowledge of his or her students and must know something of Inuit history, culture, and the geography of Nunavut-and still there will be risk. In the recent consultations mentioned earlier (Aylward, 2004; Picco, 2006) a strong desire was expressed for more Inuit language and culture in schools and for higher academic standards, but without policy created or approved by Inuit, how to modify curriculum and when to discard it remains unclear. Still, Qallunaat teachers can consider the appropriateness of curriculum and the resources they use to support it. Sometimes guidance about what Inuit value may be found in the literature about Inuit schooling, as when Crago (1992) reported that for Inuit parents "early 
physical competence of children is more highly valued than the display of spoken language" (p. 500). Consultation with Inuit colleagues and parents will help, as will attentiveness to students.

The broader problem of a foreign curriculum will not be solved by individual educators. In Alaska, Lipka (1989) noted that until communities feel that schools are there to serve them, which means curriculum defined by communities, the schools will remain foreign. This is clearly not something that an individual teacher can change, although understanding the problem and taking responsibility by questioning curricular choices may make a difference.

\section{Caring and methods}

As problematic as curriculum is, teaching methods may be an even more important area to address in cross-cultural schooling (Stairs, 1994). Values are embodied in what is taught and in how it is taught, as assumptions about power, roles, and relationships are hidden and communicated insidiously (Postman \& Weingartner, 1969). When these assumptions are incongruent with Inuit beliefs, the teaching itself can threaten culture.

Historically, Inuit learned in ways that were very different from southern school-based learning. Learning often took place by the individual observation of experts and through play that mimicked adult tasks (Bould, n.d.). It occurred through listening to stories told by adults and "backwards chaining"-completing the last step of a sequence of tasks, then the last two steps, and so on until the child had mastered the entire operation (Stairs, 1991). Student autonomy was respected, learning took place "as long as the child's interest held" (Bould, p. 11), and children were not expected to show what they could do until they could do it competently. In contrast, EuroCanadian school-based learning typically relies on oral and textual representation of abstract concepts with trial and error the expected way of developing competence. It usually takes place indoors with one teacher and many students (Stairs).

Today, even within Qallunaat-based schools, Inuit may teach in ways very different from their Qallunaat colleagues. For instance, Crago and Eriks-Brophy (1994) reported that the questioning strategies used in Qallunaat classrooms were not used by the Inuit teachers they observed. Instead of having students bid to answer questions by raising hands, spontaneous choral responses were common and Inuit teachers rarely said whether an answer was correct or not. Praise, when used, was usually given to the whole group. These practices reflect Inuit values and beliefs about childrearing, teaching, learning, and correct ways of acting.

While Qallunaat teachers probably cannot teach like Inuit teachers, understanding how Inuit traditionally learned can provide insight. Reading, close observation, and discussion will help in learning about points of conflict to avoid and useful methods to adopt. For example, disciplining a student publicly should be avoided, while hands-on activities are thought to work well with Inuit students, as is the opportunity for movement and freedom (Berger, 2001; Crago \& Eriks-Brophy, 1994; NWTECE, 1996; Stairs, 1994). Experiential learning honours Inuit epistemology which privileges personal experience as a way of knowing (Angmarlik, 1999).

Teaching methods that increase the achievement of Inuit students but do not seem to honour Inuit culture must be considered with great caution. Praise and 
strict discipline are examples of practices reported by Qallunaat to "work" in Nunavut schools, but that may be incongruent with historical Inuit practices (Berger \& Epp, 2006; Henze \& Vanett, 1993). By adopting such practices, student achievement may increase, but loss of culture may be the price of success (Berger \& Epp); the intent to care would thus be derailed. Still, culture changes over time (Kuokkanen, 2000) and Inuit may, in some circumstances, choose methods that do not resonate with Inuit culture as reported by Crago (1992) in Nunavik. Ideally, a panel of Inuit educators would be consulted about Qallunaat pedagogical decisions. Although this is not formally available, a past principal created this sort of opportunity by using biweekly early closures for group planning, giving Inuit and Qallunaat educators the chance to learn from each other (Tompkins, 1998).

One of the most egregious practices used in Nunavut schools is Qallunaatstyle assessment with its focus on tests and exams, including a high stakes high school English exam created and graded in Alberta. Qallunaat teachers in Nunavut noted that the exam is culturally insensitive and biased against ESL students (Berger, 2001). Stairs and Bernhard (2002) characterized testing as "a western cultural artefact" that, at its worst, "epitomizes the colonial mindset that continues to plague us all and particularly alienate and disrespect Aboriginal peoples" (p. 314). While a current indication of how Inuit feel about assessment is needed, moving towards holistic assessment and away from high stakes testing is likely warranted. This, again, is something that each teacher has only partial control over, and ideally Inuit would define what success looks like, and how it would be measured.

Deciding how to teach is not straightforward. With no orientation for new teachers and little inservicing that could help a teacher learn successful and respectful strategies for teaching Inuit in an ESL environment (Berger \& Epp, 2005), Qallunaat teachers must shoulder the responsibility themselves. Accepting it is an indication of caring.

\section{Learning about Inuit language and culture}

Misunderstanding can cause conflict; inadequate knowledge of Inuit culture can lead Qallunaat to misjudgement and disrespect. For example, Qallunaat educators may feel that parents are responsible for ensuring that their children are at school consistently and on time. If Inuit parents seem unwilling or unable to secure the prompt and consistent attendance of their children, some Qallunaat teachers believe that they do not care or are irresponsible (Brody, 2000). The teachers may be unaware of powerful cultural reasons for parents to refrain from interfering in their children's schooling and of circumstances in Inuit communities that may make it difficult to follow school schedules.

One reason for not becoming involved is that, in the past, the teacher was thought to know best and was expected to deal with issues related to teaching; to interfere would show a lack of trust (Okakok, 1989). Another is that Inuit value autonomy, including the autonomy of children, and do not often interfere in others' decisions (Brody, 2000; Stairs, 1991). As an example, expecting Inuit parents to make and enforce bedtimes is to expect them to do something inconsistent with historical Inuit ways. This may be very uncomfortable. 
A circumstance that may make it hard to get to school on time is the tendency for children and adults to become "upside-down" in the months of little or no darkness, sleeping in the "day" and being up all "night" (Stern, 2003). Furthermore, in the past Inuit did not structure their time arbitrarily by the numbers on a clock (Bould, n.d.), and today with many parents not involved in wage-labour the rhythm that would help facilitate adherence to the school schedule may be absent. Finally, rigid time structuring symbolizes EuroCanadian ways and might be resisted by some parents as a way of maintaining identity (Berger, Epp \& Moeller, 2006).

These considerations do not suggest exactly what to do if a student is frequently absent or often late, but they may help teachers approach the issues of poor attendance and punctuality with greater respect. The pursuit of knowledge about Inuit culture thus becomes an act of caring. Respectful ways of dealing with the issues of lateness and absence reported by Qallunaat teachers include using flexible scheduling, frequent student-led reviews, contingency work for occasional students, and maintaining a welcoming attitude (Berger, 2001). Harris (1990) wrote that when teachers demand punctuality and attendance there is much less chance of causing harm if they do not claim them as superior values, but explain them as necessary for success in Western institutions.

Another important area for Qallunaat teachers to consider is language, as language carries culture. "Teachers must be willing to learn at least the rudiments of the Native language...in order to do an effective job of teaching" (Kawagely, 1993, p. 162). Learning Inuktitut (in western Nunavut, Inuinnaqtun) would help Qallunaat teachers understand Inuit culture, the mistakes Inuit learners make speaking English, and the frustration of functioning in a second language. Beyond that, it would signal respect for Inuit, an antidote to "English...the linguistic face of colonialism" (Giroux, 1999, p. 139). Just as all non-Maori speaking faculty at the University of Auckland are required to take lessons in the Maori language (Smith 2005), a decolonizing measure, all non-Inuktitut speaking Government of Nunavut employees are required to take Inuktitut lessons, although this policy is not enforced and very few Qallunaat speak Inuktitut.

Studying the Inuit language and actively learning about Inuit culture are both signs of caring, and both require significant time commitments from teachers who may already be very busy. In the current system in Nunavut, this vision of what is needed to truly care puts too much responsibility on individual teachers. The resulting stress may, in fact, reduce teachers' ability to care (Eisler \& Levine, 2002).

\section{Self-work}

That Qallunaat schools still exist in Nunavut, structured in Qallunaat ways and responding little to the wishes of Inuit, suggests systemic racism in Canada. Most teachers, however, probably do not consider themselves to be racist. But none of us are without bias (Fiske, 2004). Fiske wrote that stereotyping and prejudice are automatic, but also that with careful attention it is possible to avoid or at least to override immediate judgements. This is critically important. The belief in the inferiority of others allows poor treatment (Zimbardo, 2004). We Qallunaat teachers need to reflect on ourselves, pay close attention to our deep feelings and 
assumptions, be aware of our privilege and position (Norquay, 1999), and explore the -isms inherited from our pasts (Nordhoff \& Kleinfeld, 1993).

Self-esteem is also needed for us to support students emotionally (Crocker, Lee \& Park, 2004), and self-knowledge is necessary for caring and fairness (Blizek, 1999). Both Blizek and Cohen (2005) described instances where unprocessed past experiences affected their abilities to be clear in the present, and they recommended knowing oneself through continual effort. I know of no easy recipe for increasing self-esteem and self-knowledge, and I suspect that each will need to choose her or his own path, be it through therapy, journaling, or other methods.

Along with the extra stress of teaching in a different culture, Qallunaat teachers in Nunavut are often isolated from friends and family. For many people these relationships provide much needed outlets for working through experiences on a regular basis. Added stress and isolation make it even more imperative that teachers engage in self-work that helps them to process events and feel through emotions as they arise, keeping them clearer and more able to be present. Teachers who are unaware are more likely to act out in the classroom and, correspondingly, less likely to act in caring ways.

\section{Caring and the school system}

No teacher could teach full-time and simultaneously pursue all of the avenues I have suggested here as important for enabling caring teaching, without burning out. Change is badly needed at the system level.

The recent Education Act consultations (Picco, 2006) and the earlier Sivuniksamut Ilinniarniq (Learning for the Future) consultations (Aylward, 2004) hold promise. The Sivuniksamut consultations were sponsored by the Nunavut Department of Education and took place across Nunavut in 2003, although the findings were first released publicly in February, 2006. The Education Act consultations ended in 2006. Both should help to inform the Department, the regional school authorities, locally elected District Education Authorities, school administrators, and teachers about Inuit desires for education. Qallunaat teachers need policy to flow from these that will help to reshape Nunavut's schools, guiding educators on questions of pedagogy and curriculum and relieving them somewhat of the need to second guess official, colonial curriculum.

More appropriate curriculum and resources should be created, relieving teachers partially of this exceptional task. Policy should be written encouraging teachers to use professional judgement in choosing what curriculum to teach and what to omit. Time should be made available for the modification or creation of curriculum and resources, and mechanisms should be introduced to foster their sharing (Berger, 2001).

As long as Qallunaat teach in Nunavut, they will need an orientation and continuing in-service programming to help them teach Inuit students in an ESL environment (Berger \& Epp, 2005). These should be prioritized, as should Inuit language lessons for all non-Inuit teachers. Release time should be designated for Qallunaat and Inuit teachers to learn from each other, perhaps in the model described by Tompkins (1998) where planning together led to increased skills and greater understanding. These measures would assist Qallunaat teachers in their commitment to caring teaching. 
Social contexts can encourage or hinder caring behaviour (Eisler \& Levine, 2002; Zimbardo, 2004) and time is needed for teachers to form caring relationships with their students (Noddings, 1992, 1996). As they design the Nunavut Education Act, policymakers should consider how best to create supportive social environments in schools and how to create the continuity necessary for caring that Noddings described. She suggested that teachers remain with the same class for three years, but many Qallunaat teachers do not even remain in Nunavut for three years. It may be that the enormous commitment needed to teach with integrity is partly responsible for early leaving, together with the frustration of not being better supported in that endeavour. This is speculative, but Nunavut teachers have expressed frustration, and the need for more professional improvement opportunities (O’Donoghue, 1998).

If student well-being is desired, schooling in Nunavut should be redesigned to prioritize it. Although there are very real roadblocks to true Inuit control of Inuit education (Berger, 2005), the creation of Nunavut and recent initiatives from the Department of Education are cause for hope. For Inuit education to foster well-being, Inuit need a real voice in what schooling will become and all teachers will need much more support than they currently receive.

\section{Caring, engagement, and respect}

A Qallunaat teacher can be a positive presence in the life of her or his Inuit students. Despite many obstacles, there is still much that teachers can do to improve the experiences of students in their classrooms. Since attitude is an important part of caring (Blizek, 1999), teachers with a strong desire to care and a commitment to learn are already well-positioned. Even in the absence of systemic reform, these teachers will be able to make a difference in their own classrooms (D’Amato, 1993; Henze \& Vanett, 1993; Tompkins, 1998).

A warm and caring environment where the teacher is seen as part of "the team" and maintains high expectations is thought to be best (Clifton \& Roberts, 1988; Stairs, 1991; Watt-Cloutier, 2000) and is something teachers can work towards. Finally, engagement and respect will be noticed by students, parents, and community members. Møller (2006) concluded that showing respect by using culturally congruent pedagogy was even more important than the congruent pedagogy itself. To be caring, Qallunaat teachers do not have to do everything well all at once, but they do need to be considering and responding to the cultural, political, and educational implications of teaching Inuit in Nunavut.

\section{Conclusion}

Qallunaat teachers in Nunavut who want to support the well-being of their Inuit students face a difficult task. They need to learn about the politics and history of Qallunaat schooling in the Eastern Arctic, and to take a political stand when deciding what and how to teach. They need a growing knowledge of Inuit culture and language to help guide their decisions, help them understand tensions, and help them show respect. Because humans are prone to prejudice and Qallunaat teachers arrive in the North with our own histories, self-awareness and self-work are also needed. Much can be done by individual teachers, and these steps will make a difference, but changes at the systemic level are urgently needed to 
support Qallunaat teachers in their caring. The most important change will be Inuit controlling Inuit education.

\section{Acknowledgement}

Thanks to Fiona Blaikie for comments on two earlier drafts of this paper, and to two anonymous reviewers for their valuable suggestions. I gratefully acknowledge SSHRC for funding that supported this writing.

\section{References}

Angmarlik, P. (1999). 'I never say what I have heard, I only tell what I have experienced, because I do not want to lie.' In P. Kulchyski, D. McCaskill, \& D. Newhouse (Eds.), In the words of elders: Aboriginal cultures in transition (pp. 273-286). Toronto: University of Toronto Press.

Aylward, L. M. (2004). Executive summary report of sivuniksamut ilinniarniq (learning for the future) consultations. Iqaluit: Nunavut Department of Education.

Berger, P. (2001). Adaptations of Euro-Canadian schools to Inuit culture in selected communities in Nunavut. Unpublished master's thesis, Lakehead University, Thunder Bay, Ontario, Canada.

Berger, P. (2005). Troubling the empire: Adapting Nunavut schools from their colonial past and present. Paper presented at the Canadian Society for Studies in Education Conference 2005, London, Ontario, Canada.

Berger, P., \& Epp, J. (2005). "There's no book and there's no guide": The expressed needs of Qallunaat educators in Nunavut. Brock Education, 15(1), 1-14.

Berger, P., \& Epp, J. (2006). Practices against culture that "work" in Nunavut schools: Problematizing two common practices. McGill Journal of Education, 41(4), 9-27.

Berger, P., Epp, J., \& Moeller, H. (2006). The predictable influences of colonialism, culture clash, and current practice on punctuality, attendance, and achievement in Nunavut schools. Canadian Journal of Native Education, 29(2), 182-205.

Blizek, W. (1999). Caring, justice, and self-knowledge. In M. Katz, N. Noddings, and K. Strike (Eds.), Justice and caring: The search for common ground in education (pp. 93-109). New York: Teachers College Press.

Bould, D. (n.d.). The Inuit way: A guide to Inuit culture. Iqaluit, Nunavut: Pauktuutit.

Brody, H. (1991). The people's land: Inuit, whites and the eastern arctic. Toronto: Douglas and McIntyre.

Brody, H. (2000). The other side of Eden: Hunters, farmers and the shaping of the world. Toronto: Douglas and McIntyre.

Clifton, R. A., \& Roberts, L. W. (1988). Social psychological dispositions and academic achievement of Inuit and non-Inuit students. Alberta Journal of Educational Research, 34(4), 332-343.

Cohen, A. (2005). The inner life of the educator: A radical perspective. Paper presented at the Canadian Society for Studies in Education Conference 2005, London, Ontario, Canada.

Crago, M. B. (1992). Communicative interaction and second language acquisition: An Inuit example. TESOL Quarterly, 26(3), 487-505.

Crago, M. B., \& Eriks-Brophy, A. (1994). Culture, conversation, and interaction: Implications for intervention. In J. F. Duchan, L. E. Hewitt, \& R. M. Sonnenmeier (Eds.), Pragmatics: From theory to practice (pp. 43-58). Englewood Cliffs, NJ: Prentice Hall.

Crocker, J., Lee, S., \& Park, L. (2004). The pursuit of self-esteem: Implications for good and evil. In A. Miller (Ed.), The social psychology of good and evil (pp. 271-302). New York: The Guildford Press.

Cummins, J. (1986). Empowering minority students. Harvard Educational Review, 56(1), 18-36.

D'Amato, J. (1993). Resistance and compliance in minority classrooms. In E. Jacob \& C. Jordan (Eds.), Minority education: Anthropological perspectives (pp. 181-208). Westport, CT: Ablex.

Doige, L. A. C. (1999). Beyond cultural differences and similarities: Student teachers encounter Aboriginal children's literature. Canadian Journal of Native Education, 24(4), 383-397. 
Eisler, R., \& Levine, D. (2002). Nature, nurture, and caring: We are not prisoners of our genes. Brain and Mind, 3, 9-52.

Fiske, S. (2004). What's in a category? Responsibility, intent and the avoidability of bias against outgroups. In A. Miller (Ed.), The social psychology of good and evil (pp. 127-140). New York: The Guildford Press.

Freire, P. (2001). Reading the world and reading the word: An interview with Paulo Freire. In W. Hare \& J. Portelli (Eds.), Philosophy of Education: Introductory readings ( $2^{\text {nd }}$ ed.) (pp. 145152). Calgary, Alberta: Detselig.

Giroux, H. (1999). The mouse that roared. Lanham, MD: Rowman \& Littlefield.

Goddard, J. T. (2002). Ethnoculturally relevant programming in northern schools. Canadian Journal of Native Education, 26(2), 124-133.

Harris, S. (1990). Two way Aboriginal schooling: Education and cultural survival. Canberra, Australia: Aboriginal Studies Press.

Hicks, J. (2005). Education in the Canadian Arctic: What difference has the Nunavut government made? Indigenous Affairs, 5(1), 8-15.

Henze, R.C., \& Vanett, L. (1993). To walk in two worlds-or more? Challenging a common metaphor of Native education. Anthropology and Education Quarterly, 24(2), 116-134.

Inuit Qaujimajatuqanginnut Task Force. (2002). The first annual report of the Inuit Qaujimajatuqanginnut (IQ) Task Force. Iqaluit, Nunavut: Author.

Jickling, B. (2003). Environmental education and environmental advocacy revisited. Journal of Environmental Education, 34(2), 20-27.

Kawagely, A. O. (1993). A Yupiaq world view: Implications for cultural, educational, and technological adaptation in a contemporary world. Unpublished doctoral dissertation, University of British Colombia, Vancouver, British Columbia, Canada.

Kelly, T. (2001). Discussing controversial issues: Four perspectives on the teacher's role. In W. Hare \& J. Portelli (Eds.), Philosophy of Education: Introductory readings $\left(2^{\text {nd }}\right.$ ed.) (pp. 222233). Calgary, AB: Detselig.

Kirkness, V. J. (1998). Our people's education: Cut the shackles; cut the crap; cut the mustard. Canadian Journal of Native Education, 22(1), 10-15.

Kuokkanen, R. (2000). Towards an "indigenous paradigm" from a Saami perspective. Canadian Journal of Native Studies, 10(2), 411-436.

Lipka, J. (1989). A cautionary tale of curriculum development in Yup'ik Eskimo communities. Anthropology and Education Quarterly, 20(3), 216-231.

Lipka, J., Mohatt, G. V., \& the Ciulistet Group. (1998). Transforming the culture of schools: Yup' $i k$ Eskimo examples. Mahwah, NJ: Lawrence Erlbaum.

McAuley, S. (1991). By our kamik strings: The Baffin writers' project and the process of empowering literacy. Our Schools/Our Selves, 3(1), 4-57.

Møller, H. (2006). Tales about tuberculosis and colonization: The sociocultural experience of tuberculosis in Nunavut. Paper presented at the $13^{\text {th }}$ International Congress on Circumpolar Health, June $12^{\text {th }}-16^{\text {th }}, 2006$, Novosibirsk, Russia.

Noddings, N. (1984). Caring. Los Angeles: University of California Press.

Noddings, N. (1992). The challenge to care in schools: An alternative approach to education. New York: Teachers College Press.

Noddings, N. (1996). The caring professional. In S. Gordon, P. Benner, and N. Noddings (Eds.), Caregiving: Readings in knowledge, practice, ethics and politics (pp. 160-172). Philadelphia: University of Pennsylvania Press.

Nordhoff, K., \& Kleinfeld, J. (1993). Preparing teachers for multicultural classrooms. Teaching and Teacher Education, 9(1), 27-39.

Norquay, N. (1999). Social difference and the problem of the 'unique individual': An uneasy legacy of child-centred pedagogy. Canadian Journal of Education, 24(2), 183-196.

Northwest Territories Education, Culture and Employment. (1996). Inuиqatigiit: The curriculum from the Inuit perspective. Yellowknife, Northwest Territories: Author.

Nunavut Social Development Council [NSDC]. (2000). On our own terms: The state of Inuit culture and society-2000. Iqaluit: Author. 
Nungak, Z. (2004). Capping the Inuktitut formal education system. Inuktitut, 94, 14-16.

O'Donoghue, F. (1998). The hunger for learning in Nunavut schools. Unpublished doctoral dissertation. University of Toronto, Toronto, Ontario, Canada.

Okakok, L. (1989). Serving the purpose of education. Harvard Educational Review, 59(4), 405422.

Portelli, J. (2001). Democracy in education: Beyond the conservative or progressive stances" in W. Hare \& J. P. Portelli (Eds.), Philosophy of Education, Introductory readings ( $2^{\text {nd }}$ ed.) (pp. 279294). Calgary, Alberta: Detselig.

Picco, E. (2006). Made-in Nunavut education act: What we've heard from Nunavummiut so far. (Insert in Nunatsiaq News, May 26 $\left.{ }^{\text {th }}, 2006\right)$. Iqaluit: Nunavut Department of Education.

Postman, N., \& Weingartner, C. (1969). Teaching as a subversive activity. New York: Dell.

Prattis, J. I., \& Chartrand, J. (1990). The cultural division of labour in the Canadian North: a statistical study of the Inuit. Canadian Review of Sociology \& Anthropology, 27(1), 49-73.

Simon, M. M. (1996). Inuit: One future - one arctic. Peterborough, Ontario: The Cider Press.

Smith, G. H. (2005). Transforming the academy: Indigenous challenges and opportunities. Presentation at the Faculty of Education, Lakehead University, Thunder Bay, Ontario, Canada.

Stairs, A. (1988). Beyond cultural inclusion: An Inuit example of indigenous educational development. In T. Skutnabb-Kangas \& J. Cummins (Eds.), Minority education: From shame to struggle (pp. 308-327). Philadelphia: Multilingual Matters.

Stairs, A. (1991). Learning processes and teaching roles in Native education: Cultural base and cultural brokerage. The Canadian Modern Language Review, 47(2), 280-294.

Stairs, A. (1994). Indigenous ways to go to school: Exploring many visions. Journal of Multilingual and Multicultural Development, 15(1), 63-76.

Stairs, A. H., \& Bernhard, J. K. (2002). Considerations for evaluating 'good care' in Canadian Aboriginal early childhood settings. McGill Journal of Education, 37(3), 309-330.

Stern, P. (2003). Upside-down and backwards: Time discipline in a Canadian Inuit town. Anthropologica, 45(1), 147-162.

Tester, F. J., \& Kulchyski, P. (1994). Tammarniit (mistakes): Inuit relocation in the eastern Arctic 1939-63. Vancouver: UBC Press.

Tester, F. J. (2006). Iglutaq (in my room): The implications of homelessness for Inuit (Rep. for The Harvest Society, Kinngait, Nunavut). Vancouver, British Columbia, Canada: Author.

Tompkins, J. (1998). Teaching in a cold and windy place: Change in an Inuit school. Toronto: University of Toronto Press.

Tompkins, J. (2002). Learning to see what they can't: Decolonizing perspectives on Indigenous education in the racial context of Nova Scotia. McGill Journal of Education, 37(3), 405-422.

United Nations. (2006). United Nations declaration on the rights of indigenous peoples. Retrieved October $10^{\text {th }}, 2006$, from http:// www.usask.ca/nativelaw/ddir.html

Van Meenen, M. A. (1994). Government policies on education for the native peoples of Siberia and the Northwest Territories 1900-1990: A historical examination. Unpublished doctoral dissertation, Dalhousie University, Halifax, Nova Scotia, Canada.

Watt-Cloutier, S. (2000). Honouring our past, creating our future: Education in Northern and remote communities. In M. B. Castellano, L. Davis, and L. Lahache (Eds.), Aboriginal education: Fulfilling the promise (pp. 114-128). Vancouver: UBC Press.

Wolforth, J. (1998). Inuit social studies: a variant on a common theme. Teaching and Teacher Education, 14(6), 565-577.

Zimbardo, P. (2004). A situationist perspective on the psychology of evil. In A. Miller (Ed.), The social psychology of good and evil (pp. 21-50). New York: The Guildford Press. 